Article ID: 7333

DOI: 10.5586/aa.7333

Publication History

Received: 2020-05-06

Accepted: 2020-06-14

Published: 2020-10-15

\section{Handling Editor}

Bożena Denisow; University of Life Sciences in Lublin, Poland; https://orcid.org/0000-00016718-7496

\section{Authors' Contributions} ZNB and MAA: research design and performing experiments;

ZNB, MAA, VO, and IK: data evaluation and discussion, writing - original draft preparation; VO and IK: writing review and editing

\section{Funding}

None.

\section{Competing Interests}

No competing interests have been declared.

\section{Copyright Notice}

(c) The Author(s) 2020. This is an open access article distributed under the terms of the Creative Commons Attribution License, which permits redistribution, commercial and noncommercial, provided that the article is properly cited.

\title{
Effects of Altitude on the Pomological Characteristics and Chemical Properties of 'Chandler' Walnuts: A Case Study in Uşak Province
}

\author{
Zeki Nurhan Büyüksolak (iD) 1 , Mehmet Atilla Aşkın (iD) ${ }^{2}$, \\ İbrahim Kahramanoğlu $\left(^{2}{ }^{2}\right.$, Volkan Okatan $\left(^{3^{*}}\right.$ \\ ${ }^{1}$ Suleyman Demirel University, Isparta, Turkey \\ ${ }^{2}$ European University of Lefke, Gemikonağı, Turkey \\ ${ }^{3}$ Department of Horticulture, Faculty of Agriculture and Natural Sciences, Uşak University, \\ Uşak, Turkey \\ *To whom correspondence should be addressed. Email: volkan.okatan@usak.edu.tr
}

\begin{abstract}
This research was conducted to investigate some quality parameters of nuts of walnut (Juglans regia L.) 'Chandler' grown at different altitudes. Studies were conducted in Eşme Town, Uşak Province, in three different villages situated at an average altitude of $650 \mathrm{~m}, 800 \mathrm{~m}$, and $900 \mathrm{~m}$. Studies were conducted in Karaahmetli, Takmak, and Yeşilkavak villages in the 2012-2013 production year and orchards with similar soil and topography characteristics were selected. Plant protection, plant production, and other cultivation practices in the sampled orchards were also noted and orchards with the same attributes were selected. During the harvesting period, regular measurements were taken to determine correct time for harvesting. Nuts were hand-harvested when the color of the membrane separating the kernel and outer parts turned brown. A total of 3540 nuts were randomly selected and harvested from the three orchards and 15 of those were randomly selected for further analysis. Nut weight, internal (kernel) weight, shell thickness, kernel color, dry matter, moisture, ash, protein, oil, mineral matter, and free fatty acid composition were determined. Results showed that the site altitude significantly influences walnut's quality and it is highly important to consider the site altitude as a factor before planting new orchards. Results showed that nut height, nut width, nut length, nut weight, kernel weight, shell thickness, oil content, phosphorus content, magnesium content, oleic acid, and linolenic acid increase with an increase in altitude. On the other hand, kernel ratio, total nitrogen, and protein content were found to decrease with increasing site altitude.
\end{abstract}

\section{Keywords}

free fatty acids; protein content; minerals; palmitic acid; oleic acid; linoleic acid

\section{Introduction}

Walnut (Juglans regia L.) is an ancient nut originating in Central Asia (Fjellstrom \& Parfitt, 1994). Nuts are known to be among the oldest food sources for not only human beings but also for animals (Woodroof, 1967). Walnut had the second place after almonds in the group of nuts until 2013, and then took the first place in total production. The top five largest producers in 2017, in descending order of total production, were China, the USA, Iran, Turkey, and Mexico (Food and Agriculture Organization, 2019). Walnuts have a long history of cultivation throughout the world and are easily adapted to different climates (McGranahan \& Leslie, 1990). Walnuts are rich in calories $\left(654 \mathrm{kcal} 100 \mathrm{~g}^{-1}\right)$, proteins $(15.2 \mathrm{~g}$

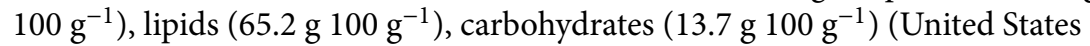


Department Agriculture, 2016), and unsaturated fatty acids, i.e., oleic acid, linoleic acid, and linolenic acid (Martínez et al., 2010). Walnuts have no cholesterol and are very beneficial for human health. Jahanbani et al. (2016) reported that walnuts are high in antioxidants and exhibit possible anticancer effects by protecting against breast and colon cancer. Recent studies have also shown that walnuts are rich in health-related phytochemical compounds (Cosmulescu \& Trandafir, 2015; Kafkas et al., 2017). They are also a good source of flavonoids and phenolic acids, and have high antioxidant activity (Beyhan et al., 2016; Bujdosó et al., 2014; Gharibzahedi et al., 2014: Polat et al., 2015). These phytochemicals with high antioxidant activity are known to protect human body from free radicals (Nunes et al., 2012).

Walnut has a wide genetic diversity developed through evolution under challenging environmental conditions leading to a vast differentiation in the walnut germplasm and significantly influencing the chemical composition of the fruits (Wan et al., 2017; Yang, 2005). The vast genetic variation arises mainly from seed-based plantations and from high heterozygosity (Bernard et al., 2018). This variability has led to intensive research on walnut germplasm throughout the world, as reported in Spain (Aletà \& Ninot, 1997), Iran (Atefi, 1997), the Anatolia (Akça \& Şen, 2001; Balci et al., 2001; Yarilgaç et al., 2001), China (Gunn et al., 2010), Central Asia (Molnar et al., 2011), and Italy (Poggetti et al., 2017). Archaeological research in Anatolia indicated that the people living there for at least 3,000 years have known and benefited from walnuts (Soylu \& Ertürk, 2001). Characteristics of the fruits not only vary among the different germplasm, but also differ within the similar varieties when they are grown under different conditions. The pomological characteristics and chemical composition of fruits might be influenced by the topography of the production area (Örmeci \& Aşkın, 2017), growing altitudes (Eskimez et al., 2019; Usanmaz et al., 2018), production systems (Patumi, 1999), and variety (Baccouri et al., 2007; Okatan et al., 2017). Recent studies showed that the morphology of a walnut shoot is affected by its position in the canopy and that shoot morphology is directly related with the number and size of the fruits (Valdebenito et al., 2017).

Fruit production requires longer investment compared to vegetable production and it is important to know the changes in the pomological characteristics of the fruit depending on the different environmental conditions. Selection of the best suitable conditions for different walnut varieties is an important step for ensuring higher fruit quality to consumers and for improving profitability of investments. Today, the most commonly and globally produced walnut cultivar is 'Chandler' throughout the world (USDA, 2016). Kapluhan (2015) noted that the 'Chandler' walnut covers about half of the walnut production in Kirşehir, Konya, and Nevşehir cities in Turkey. Phenological, pomological, and other plant characteristics are very crucial for the selection of suitable germplasm for ecological conditions and to achieve economical cultivation. According to the authors of the present work, no specific studies exist on the differentiation of the pomological characteristics of the 'Chandler' walnut depending on altitudes. Thus, the present research was conducted to investigate some quality parameters of the 'Chandler' walnut grown at different altitudes.

\section{Materials and Methods}

\subsection{Materials}

The nuts of the 'Chandler' cultivar (Juglans regia L.) were considered in the present study. Nut samples were collected from three different walnut orchards, located in Uşak Province at different altitudes, during 2012-2013 growing season. The soil type and topography of the orchards were similar. The three villages where the walnut orchards were located were Karaahmetli (900 m), Takmak (800 m), and Yeşilkavak $(650 \mathrm{~m})$. Plant nutrition, crop protection, and other cultivation practices in the orchards were noted for the study years. Nut samples were collected at commercial maturity when the membrane turned brown and separated from the hard shell. The altitudes of the walnut orchards were determined using Google Earth and geographic information system (GIS) of the Department of Information Technologies in Uşak Province. A total of 35-40 nuts were randomly selected and 
harvested from the three orchards, and 15 of those were randomly selected for further analysis. Trees affected by pests and/or diseases were avoided, and only vigorous and productive trees were chosen and represented the average orchard.

\subsection{Methods}

Nut samples were quickly transferred to laboratory where the inner (kernel) parts were immediately separated from their green shells and put into labeled net bags. They were allowed to dry in a cool, ventilated, and moisture-free shade area to prevent any escalation of moisture and possible darkening of the nut. The physical characteristics of the nuts were determined according to following order:

1. Nut dimensions (length, width, and height) were firstly determined with a digital caliper (sensitive to $\pm 0.01 \mathrm{~mm}$ ).

2. Nut weight (whole fruit: kernel with peel) was determined with digital balance (sensitive to $\pm 0.01 \mathrm{~g}$ ) after drying at room temperature according to Şen (1980).

3. Hereafter, the peel was broken, the kernel was separated from the peel and the kernel weight was determined with digital balance.

4. At that point, nut peel thickness was also determined from the center of each peel by using digital caliper.

5. Kernel yield was then calculated by using the kernel weight and total weight and expressed as \% according to Şen (1980) and Beyhan (1993).

6. The peel color and kernel color $\left(\mathrm{CIE} \mathrm{L}^{*} \mathrm{a}^{*} \mathrm{~b}^{*}\right)$ of the nuts were determined with Minolta CR-400 colorimeter (Minolta Corp, Ramsey, NJ, USA).

7. The kernel color of the nuts was categorized according to the standards of Dried Fruit Association (DFA) as extra light, light, light amber, and amber. Furthermore, the chemical characteristics of the kernel (dry matter, oil percentage, nitrogen content, protein, ash, mineral matter, acids, and free fatty acid composition) were also determined after crushing in a mortar. After crushing, $10 \mathrm{~g}$ of kernel samples were taken and dried in an oven at $105^{\circ} \mathrm{C}$ for 4 to 6 hours to determine the dry matter content.

8. For the determination of ash content, the Association of Official Analytical Chemists (2000) method was followed where $1.0 \mathrm{~g}$ of kernel sample was taken into ash oven and the temperature was increased gradually. Samples were kept at $100{ }^{\circ} \mathrm{C}$ for $30 \mathrm{~min}, 200{ }^{\circ} \mathrm{C}$ for $30 \mathrm{~min}, 400^{\circ} \mathrm{C}$ for $60 \mathrm{~min}$, and $550{ }^{\circ} \mathrm{C}$ for 330 min. The final and initial weight was then used to calculate ash percentage.

9. Oil percentage of the samples was determined according to the formula of Manirakiza et al. (2001) by using Extraction Unit E-816 HE (Buchi AG, Switzerland).

10. Nitrogen content of the samples was determined according to the Kjeldahl method (Kacar \& İnal, 2008). Calculation of the protein content (\%) was carried out according to the formula of James (1995) by multiplying the nitrogen percentage with 6.25 .

11. Furthermore, mineral analysis was carried with ICP-OES according to the method of NMKL NordVal International (2007).

12. Finally, free fatty acid concentrations were determined by following the method of Yılmazer and Seçilmiş (2006) via GC/MS.

\subsection{Data Analysis}

Raw data of the present study were subjected to one-way ANOVA for all parameters separately and the mean separation was performed with Tukey's honesty significance analysis at $p \leq 0.05$.

\section{Results}

\subsection{Physical Characteristics of Nuts}

The results showed that the nut length, nut width, and nut height varied from 39.73 $\mathrm{mm}$ to $43.70 \mathrm{~mm}$, from $30.56 \mathrm{~mm}$ to $33.48 \mathrm{~mm}$, and from $31.92 \mathrm{~mm}$ to $34.96 \mathrm{~mm}$, 
respectively, for the different altitudes (Table 1). It was concluded from the results that the nut height, nut width, and nut length increased with the increasing altitude. The nut weight and kernel weight also exhibited a significant increase as the altitude increased. The average nut weight was $8.77 \mathrm{~g}$ at the lowest altitude and $13.35 \mathrm{~g}$ at the highest. The average kernel weight was also increased as the altitude increased. However, the increase in the kernel ratio was found to be lower than the total nut weight. Therefore, in contrast to the nut weight and kernel weight results, the kernel ratio was found to decrease with the increase in the altitude. The color of the nut is an important parameter in determination of the walnut quality. All nuts analyzed in the present study were found to have an extra light color according to the DFA color scale for walnuts. However, there were differences in the color categories of the walnuts grown at the different altitudes; the lightness value $\left(L^{\star}\right)$ of the nuts was found to decrease as the altitude increased.

Table 1 Changes in some physical parameters of walnuts 'Chandler' according to growing altitude.

\begin{tabular}{llll}
\hline Physical characteristics & Yeşilkavak $(650 \mathrm{~m})$ & Takmak $(800 \mathrm{~m})$ & Karaahmetli $(900 \mathrm{~m})$ \\
\hline Nut length $(\mathrm{mm})$ & $39.73 \pm 0.36 \mathrm{~B}$ & $43.70 \pm 0.40 \mathrm{~A}$ & $42.69 \pm 0.26 \mathrm{~A}$ \\
Nut width $(\mathrm{mm})$ & $30.56 \pm 0.26 \mathrm{~B}$ & $33.48 \pm 0.12 \mathrm{~A}$ & $32.90 \pm 0.17 \mathrm{~A}$ \\
Nut height $(\mathrm{mm})$ & $31.92 \pm 0.29 \mathrm{~B}$ & $34.96 \pm 0.14 \mathrm{~A}$ & $34.86 \pm 0.20 \mathrm{~A}$ \\
Nut weight $(\mathrm{g})$ & $8.77 \pm 0.24 \mathrm{C}$ & $12.22 \pm 0.16 \mathrm{~B}$ & $13.35 \pm 0.18 \mathrm{~A}$ \\
Kernel weight $(\mathrm{g})$ & $4.14 \pm 0.17 \mathrm{~B}$ & $5.40 \pm 0.11 \mathrm{~A}$ & $5.61 \pm 0.09 \mathrm{~A}$ \\
Kernel ratio $(\%)$ & $47.58 \pm 5.23 \mathrm{~A}$ & $44.40 \pm 5.88 \mathrm{~B}$ & $42.16 \pm 1.90 \mathrm{~B}$ \\
Shell thickness / at top $(\mathrm{mm})$ & $1.55 \pm 0.034 \mathrm{~B}$ & $1.50 \pm 0.027 \mathrm{~B}$ & $1.97 \pm 0.041 \mathrm{~A}$ \\
Shell thickness / side $(\mathrm{mm})$ & $2.50 \pm 0.075 \mathrm{~B}$ & $2.54 \pm 0.053 \mathrm{~B}$ & $3.27 \pm 0.062 \mathrm{~A}$ \\
Color CIE L* value & $56.36 \pm 0.52 \mathrm{~A}$ & $50.37 \pm 0.52 \mathrm{~B}$ & $49.93 \pm 0.41 \mathrm{~B}$ \\
Color CIE a* value & $13.55 \pm 0.13 \mathrm{~A}$ & $13.81 \pm 0.12 \mathrm{~A}$ & $13.61 \pm 0.12 \mathrm{~A}$ \\
Color CIE b* value & $22.93 \pm 0.40 \mathrm{~A}$ & $22.80 \pm 0.27 \mathrm{~A}$ & $21.62 \pm 0.20 \mathrm{~B}$ \\
\hline
\end{tabular}

Values followed by the same letter or letters within the same row are not significantly different at 5\% level (Tukey's HSD multiple range test).

\subsection{Chemical Characteristics of Nuts}

The dry matter (96.74\%-96.86\%) content of the walnuts was found to have no significant relationship with the growing altitude. There was no significant difference in the dry matter and moisture content in the walnuts grown at the different altitudes (Table 2). The oil content in the walnuts was found to increase as the altitude increased. It was $61.73 \%$ at the $650 \mathrm{~m}$ altitude and increased to $65.14 \%$ and $65.91 \%$ at $800 \mathrm{~m}$ and $900 \mathrm{~m}$, respectively. Contrary to the oil content, the nitrogen content of the walnuts was found to decrease as the growing altitude increased. Similar to the total nitrogen, as expected, the protein content in the walnuts decreased as the altitude increased. The highest protein content (17.25\%) was noted in nuts from the lowest growing altitude $(650 \mathrm{~m})$, whereas the lowest protein content $(14.81 \%)$ was determined in nuts from the highest growing altitude $(900 \mathrm{~m})$. The ash content of the nut samples varied from $1.60 \%$ to $1.75 \%$ and no significant relationship was observed between ash contents and the growing altitude.

Table 2 Changes in some chemical parameters of 'Chandler' walnuts according to growing altitude.

\begin{tabular}{llll}
\hline Chemical characteristics & Yeşilkavak $(650 \mathrm{~m})(\%)$ & Takmak $(800 \mathrm{~m})(\%)$ & Karahmetli $(900 \mathrm{~m})(\%)$ \\
\hline Dry matter & $96.77 \pm 0.028 \mathrm{~A}$ & $96.74 \pm 0.05 \mathrm{~A}$ & $96.86 \pm 0.042 \mathrm{~A}$ \\
Oil & $61.73 \pm 0.45 \mathrm{~B}$ & $65.14 \pm 0.20 \mathrm{~A}$ & $65.91 \pm 0.17 \mathrm{~A}$ \\
Total nitrogen & $3.255 \pm 0.40 \mathrm{~A}$ & $2.915 \pm 0.12 \mathrm{AB}$ & $2.795 \pm 0.06 \mathrm{~B}$ \\
Protein & $17.25 \pm 2.11 \mathrm{~A}$ & $15.45 \pm 0.61 \mathrm{AB}$ & $14.81 \pm 0.32 \mathrm{~B}$ \\
Ash & $1.75 \pm 0.00 \mathrm{~A}$ & $1.60 \pm 0.01 \mathrm{C}$ & $1.70 \pm 0.02 \mathrm{~B}$ \\
\hline
\end{tabular}

Values followed by the same letter or letters within the same row are not significantly different at 5\% level (Tukey's HSD multiple range test). 


\subsection{Mineral Content of Nuts}

Changes in the mineral contents in the walnuts according to growing altitude are shown in Table 3. As shown by the results obtained, the nuts were found to have high amounts of phosphorus, magnesium, calcium, and potassium. Among these four most abundant minerals, phosphorus and magnesium were found to increase as the growing altitude increased. No significant correlation was obtained for calcium, whereas potassium was found to show a nonlinear increase as the altitude increased. The zinc content in the nuts decreased as the growing altitude increased, but no relationships with the altitude were detected in the case of the other minerals, i.e., manganese, iron, copper, and sodium.

Table 3 Changes in some minerals of 'Chandler' walnuts according to growing altitude.

\begin{tabular}{llll}
\hline Minerals & Yeşilkavak $(650 \mathrm{~m})\left(\mathrm{mg} 100 \mathrm{~g}^{-1}\right)$ & Takmak $(800 \mathrm{~m})\left(\mathrm{mg} 100 \mathrm{~g}^{-1}\right)$ & Karaahmetli $(900 \mathrm{~m})\left(\mathrm{mg}^{\left.100 \mathrm{~g}^{-1}\right)}\right.$ \\
\hline Phosphorus (P) & $417 \pm 0.20 \mathrm{~B}$ & $434 \pm 0.24 \mathrm{AB}$ & $501 \pm 0.06 \mathrm{~A}$ \\
Magnesium $(\mathrm{Mg})$ & $141 \pm 0.07 \mathrm{~B}$ & $141 \pm 0.08 \mathrm{~B}$ & $158 \pm 0.07 \mathrm{~A}$ \\
Calcium $(\mathrm{Ca})$ & $148 \pm 0.04 \mathrm{~B}$ & $112 \pm 0.07 \mathrm{C}$ & $202 \pm 0.06 \mathrm{~A}$ \\
Potassium $(\mathrm{K})$ & $441 \pm 0.0 \mathrm{~B}$ & $509 \pm 0.04 \mathrm{~A}$ & $488 \pm 0.10 \mathrm{~A}$ \\
Zinc $(\mathrm{Zn})$ & $1.3 \pm 0.0 \mathrm{~A}$ & $1.3 \pm 0.0 \mathrm{~A}$ & $1.1 \pm 0.0 \mathrm{~A}$ \\
Manganese $(\mathrm{Mn})$ & $7.6 \pm 0.0 \mathrm{~A}$ & $2.5 \pm 0.0 \mathrm{C}$ & $4.1 \pm 0.0 \mathrm{~B}$ \\
Iron (Fe) & $0.95 \pm 0.0 \mathrm{~B}$ & $0.85 \pm 0.0 \mathrm{C}$ & $1.05 \pm 0.0 \mathrm{~A}$ \\
Copper $(\mathrm{Cu})$ & $0.5 \pm 0.0 \mathrm{~A}$ & $0.4 \pm 0.0 \mathrm{~A}$ & $0.4 \pm 0.0 \mathrm{~A}$ \\
Sodium $(\mathrm{Na})$ & $0.4 \pm 0.0 \mathrm{~A}$ & $0.3 \pm 0.0 \mathrm{~A}$ & $0.3 \pm 0.0 \mathrm{~A}$ \\
\hline
\end{tabular}

Values followed by the same letter or letters within the same row are not significantly different at 5\% level (Tukey's HSD multiple range test).

\subsection{Free Fatty Acids}

The types of fatty acids and the percentage changes in their content in the walnuts relative to the growing altitudes are presented in Table 4 . As demonstrated by the results obtained, linoleic acid was present at the highest concentration $(58.185 \%-$ $58.607 \%)$ and was followed by oleic acid (12.957\%-14.182\%) and linolenic acid (12.038\%-12.911\%). Among these four most abundant fatty acids, the content of linoleic acid was not correlated with the growing altitude, but the amounts of oleic acid and linolenic acid were found to increase as the altitude increases. Oleic acid is a monounsaturated fatty acid while linolenic acid, likewise linoleic acid, is a saturated fatty acid.

Table 4 Changes in free fatty acids of 'Chandler' walnuts according to growing altitude.

\begin{tabular}{llll}
\hline Free fatty acids & Yeşilkavak $(650 \mathrm{~m})(\%)$ & Takmak $(800 \mathrm{~m})(\%)$ & Karaahmetli $(900 \mathrm{~m})(\%)$ \\
\hline Myristic acid (C14:0) & $0.061 \pm 0.0 \mathrm{~B}$ & $0.016 \pm 0.0 \mathrm{C}$ & $0.085 \pm 0.0 \mathrm{~A}$ \\
Pentadecanoic acid (C15:0) & $0.020 \pm 0.0 \mathrm{~A}$ & $0.013 \pm 0.0 \mathrm{~B}$ & $0.018 \pm 0.0 \mathrm{AB}$ \\
cis-Pentadecanoic acid (C15:1) & $0.013 \pm 0.0 \mathrm{~A}$ & $0.016 \pm 0.0 \mathrm{~A}$ & $0.023 \pm 0.0 \mathrm{~A}$ \\
Palmitic acid (C16:0) & $8.606 \pm 0.0 \mathrm{~B}$ & $9.399 \pm 0.11 \mathrm{~A}$ & $8.714 \pm 0.02 \mathrm{~B}$ \\
Palmitoleic acid (C16:1 C7) & $0.082 \pm 0.04 \mathrm{~A}$ & $0.062 \pm 0.0 \mathrm{~B}$ & $0.076 \pm 0.0 \mathrm{AB}$ \\
9-Heksenoik acid (C16:1 C9) & $0.082 \pm 0.0 \mathrm{~A}$ & $0.081 \pm 0.0 \mathrm{~A}$ & $0.076 \pm 0.0 \mathrm{~A}$ \\
Heptadecanoic acid (C17:0) & $0.092 \pm 0.0 \mathrm{~A}$ & $0.113 \pm 0.0 \mathrm{~A}$ & $0.126 \pm 0.01 \mathrm{~A}$ \\
Stearic acid (C18:0) & $3.073 \pm 0.05 \mathrm{~B}$ & $3.288 \pm 0.03 \mathrm{~A}$ & $3.133 \pm 0.07 \mathrm{AB}$ \\
Oleic acid (C18:1 n9c) & $12.957 \pm 0.17 \mathrm{~B}$ & $13.219 \pm 0.00 \mathrm{~B}$ & $14.182 \pm 0.14 \mathrm{~A}$ \\
Conjugated linoleic acid (C18:1 t10) & $1.1385 \pm 0.0 \mathrm{~A}$ & $1.1035 \pm 0.04 \mathrm{~A}$ & $1.1365 \pm 0.01 \mathrm{~A}$ \\
Linoleic acid (C18:2) & $58.607 \pm 0.47 \mathrm{~A}$ & $58.185 \pm 0.13 \mathrm{~A}$ & $58.343 \pm 0.40 \mathrm{~A}$ \\
Linolenic acid (C18:3) & $12.038 \pm 0.05 \mathrm{~B}$ & $12.262 \pm 0.02 \mathrm{~B}$ & $12.911 \pm 0.17 \mathrm{~A}$ \\
Arachidonic acid (C20:0) & $0.4815 \pm 0.0 \mathrm{~A}$ & $0.0330 \pm 0.0 \mathrm{C}$ & $0.1705 \pm 0.01 \mathrm{~B}$ \\
\hline
\end{tabular}

Values followed by the same letter or letters within the same row are not significantly different at 5\% level (Tukey's HSD multiple range test). 


\section{Discussion}

The results of the nut length, nut width, and nut height obtained in the present study agree with the findings reported by Oguz et al. (2017). Our study clearly showed that these three characteristics of the nuts increased as the altitude increased. The average nut weight, kernel weight, and kernel ratio results shown in the present study are in agreement with some previous reports (Aslansoy, 2012; Beyhan, 2009; Muradoğlu \& Balta, 2010; Şimşek, 2010; Ünver \& Çelik, 2005). Shell thickness is an important quality parameter determining nut crackability. We documented that the shell thickness at both the top and the side increased with the increasing altitude. The nut shell thickness in the present study was found to be higher than that reported by Koyuncu and Aşkın (1995) for 39 different germplasm in Denizli Province, Turkey. However, our results are in agreement with the findings shown by Godeanu et al. (1997) in four different germplasm in Romania, and with the notes reported by Şimşek (2010) in Mardin Province, Turkey. Similarly, the study conducted by Amiri et al. (2010) showing that kernel weight is significantly correlated with the shell thickness supports our findings.

In terms of the average dry matter and moisture contents, our results are in agreement with the studies carried out by Başer et al. (2016). The oil content obtained in the present study is higher than that reported by Muradoğlu and Balta (2010) but similar to the values documented by Savage (2001), Doğan and Akgül (2005), Çelik et al. (2011), Gharibzahedi et al. (2014), Keles et al. (2014), and Yarılgaç and Yılmaz (2016). However, these previous studies only reported the oil content in walnuts but did not study the influence of growing conditions on the oil content. To our knowledge, no previous studies aimed to determine the influence of the growing altitude on the protein content in walnuts. However, in several previous reports (e.g., Çelik et al., 2011; Koyuncu et al., 2005; Yarılgaç et al., 2003; Yarılgaç \& Yllmaz, 2016), the protein levels in walnut differed depending on the growing environments. The results of the ash content (from $1.60 \%$ to $1.75 \%$ ) obtained in the present study supported the findings reported by Yarılgaç et al. (2003) but were lower than that documented by Gharibzahedi et al. (2014).

The nuts analyzed in this study were found to have a high amount of phosphorus, magnesium, calcium, and potassium. The results of the average potassium and magnesium concentrations are in agreement with the research conducted by Yerlikaya et al. (2012). In turn, the iron concentration was lower than that determined by Tapia et al. (2013). Concurrently, the manganese concentration was higher compared to that reported by Tapia et al. (2013). To the best of our knowledge, there are no results showing a relationship between the walnut quality parameters and the growing altitude. However, the results of our analyses and other reports showing the environmental impact on walnut components suggest that the altitude has a significant influence on the quality parameters of walnuts, including minerals.

The concentration of linoleic acid in the walnuts analyzed in the current study confirms the findings reported by Beyazit and Sümbül (2012), but the contents of palmitic acid and linolenic acid are higher. In turn, the amounts of oleic acid and stearic acid are lower compared to those presented by Beyazit and Sümbül (2012). The oleic acid concentration obtained in the present study is also lower than that documented by Yerlikaya et al. (2012) and Şimşek (2016). The linoleic acid concentration in the walnuts determined in our study is in agreement with the results reported by Yerlikaya et al. (2012) and Şimşek (2016). Our results also agree with the study conducted by Beck et al. (2014), who reported that walnuts are rich in linolenic acid. Overall, the concentrations and diversity in the fatty acid composition are in agreement with the results presented by Bouabdallah et al. (2014) and Gao et al. (2019).

It is possible to conclude that some of the walnut fruit characteristics are significantly affected by the altitude, whereas some others are not. It was also found that 'Chandler' nuts may exhibit different response to the growing altitude, compared to other walnut cultivars. 


\section{Conclusion}

Results of the present study suggested that site altitude has significant influence both on the pomological characteristics and on the fatty acid composition of walnuts. Results showed that nut height, nut width, nut length, nut weight, kernel weight, shell thickness, oil content, phosphorus content, magnesium content, oleic acid, and linolenic acid increased with growing altitude. On the other hand, some other characteristics, i.e., kernel ratio, total nitrogen, and protein content showed a decreasing trend while the site altitude increased. Site altitudes of the present study were found to have slight influence on the lightness of kernel color but did not affect the nut color. Walnuts at higher altitudes were found to have slightly darker kernel than those at lower altitudes. Some other parameters such as dry matter, moisture content, ash content, calcium content, potassium content, and linoleic acid were also noted to have no significant relationship with the site altitude. In conclusion, results showed that the site altitude significantly influenced walnuts quality and it is highly important to consider the site altitude as a factor before planting new orchards.

\section{References}

Akça, Y., \& Şen, S. M. (2001). Study on the selection of superior walnut trees in Hizan (Bitlis) populations. Acta Horticulturae, 544, 115-118. https://doi.org/10.17660/ActaHortic.2001.544.14

Aletà, N., \& Ninot, A. (1997). Field evaluation of Juglans regia selected clones from seedling populations of Mediterranean and Atlantic Spanish coast. Acta Horticulturae, 442, 63-67. https://doi.org/10.17660/ActaHortic.1997.442.6

Amiri, R., Vahdati, K., Mohsenipoor, S., Mozaffari, M. R., \& Leslie, C. (2010). Correlations between some horticultural habits in walnut. HortScience, 45(11), 1690-1694. https://doi.org/10.21273/HORTSCI.45.11.1690

Aslansoy, B. (2012). Sultandă̆ı (Afyon) yöresi cevizlerinin (Juglans regia L.) seleksiyon yoluyla ıslahı üzerine araştırmalar [Research on breeding of walnut (Juglans regia L.) in Sultandağı (Afyon) region by selection [Master's thesis, Şelçuk University]. http://hdl.handle.net/123456789/1084

Association of Official Analytical Chemists. (2000). Official methods of analysis (17th ed.). AOAC.

Atefi, J. (1997). Study on phenological and pomological characters on walnut promising clones in Iran. Acta Horticulturae, 442, 101-108. https://doi.org/10.17660/ActaHortic.1997.442.13

Baccouri, B., Ben-Temime, S., Taamalli, W., Daoud, D., M’sallem, M., \& Zarrouk, M. (2007). Analytical characteristics of virgin olive oils from two new varieties obtained by controlled crossing on Meski variety. Journal of Food Lipids, 14, 19-34. https://doi.org/10.1111/j.1745-4522.2006.00067.x

Balci, I., Balta, A., Kazankaya, A., \& Şen, S. M. (2001). Promising native walnut genotypes (Juglans regia L.) of the east Black Sea region of Turkey. Journal American Pomological Society, 55(4), 204-208.

Başer, S., Kazankaya, A., Doğan, A., Yaviç, A., \& Çelik, F. (2016). Van Gölü havzasında soğuklara dayanıklı ceviz (Juglans regia L.) genotiplerinin bazı fiziksel ve kimyasal özellikleri [Some physical and chemical properties of cold-resistant walnut genotypes (Juglans regia L.) from Van Lake basin]. YYÜ Journal of Agricultural Science, 26(4), 632-641. https://doi.org/10.29133/yyutbd.267173

Bayazit, S., \& Sümbül, A. (2012). Determination of fruit quality and fatty acid composition of Turkish walnut (Juglans regia L.) cultivars and genotypes grown in subtropical climate of eastern mediterranean region. International Journal of Agriculture \& Biology, 14(3), 419-424.

Beck, J. J., Mahoney, N. E., Cook, D., Higbee, B. S., Light, D. M., Gee, W. S., \& Baig, N. (2014). Comparison of the volatile emission profiles of ground almond and pistachio mummies: Part 2. Critical changes in emission profiles as a result of increasing the water activity. Phytochemistry Letters, 8, 220-225. https://doi.org/10.1016/j.phytol.2014.01.004

Bernard, A., Lheureux, F., \& Dirlewanger, E. (2018). Walnut: Past and future of genetic improvement. Tree Genetics \& Genomes, 14, Article 1. https://doi.org/10.1007/s11295017-1214-0

Beyhan, Ö. (1993). Darende cevizlerinin (J. regia L.) seleksiyon yoluyla islahı üzerinde araştırmalar [Research on the breeding of Darende walnuts (J. regia L.) by selection] [Unpublished doctoral dissertation]. Yüzüncü Yıl University. 
Beyhan, Ö. (2009). Akyazı bölgesi cevizlerinin (Juglans regia L.) seleksiyon yoluyla islahı üzerine araştırmalar [Relationships researchs on breeding by selection of walnut (Juglans regia L.) forms in Akyazı Province]. Bahçe, 38(2), 1-8.

Beyhan, Ö., Gozlekci, S., Gundogdu, M., \& Ercişli, S. (2016). Physico-chemical and antioxidant characteristics in fruits of walnut (Juglans regia L.) genotypes from inner Anatolia. Notulae Botanicae Horti Agrobotanici Cluj-Napoca, 44(2), 586-592. https://doi.org/10.15835/nbha44210304

Bouabdallah, I., Bouali, I., Martinez-Force, E., Albouchi, A., Perez-Camino, M. C., \& Boukhchina, S. (2014). Composition of fatty acids, triacylglycerols and polar compounds of different walnut varieties (Juglans regia L.) from Tunisia. Natural Product Research, 28, 1826-1833. https://doi.org/10.1080/14786419.2014.950573

Bujdosó, G., Végvári, G., Hajnal, V., Ficzek, G., \& Tóth, M. (2014). Phenolic profile of the kernel of selected Persian walnut (Juglans regia L.) cultivars. Notulae Botanicae Horti Agrobotanici Cluj-Napoca, 42(1), 24-29. https://doi.org/10.15835/nbha4219400

Cosmulescu, S., Trandafir, I., Nour, V., \& Botu, M. (2015). Total phenolic, flavonoid distribution and antioxidant capacity in skin, pulp and fruit extracts of plum cultivars. Journal of Food Biochemistry, 39, 64-69. https://doi.org/10.1111/jfbc.12112

Çelik, F., Cimrin, K. M., \& Kazankaya, A. (2011). Some physical and chemical characteristics of promising walnuts (Juglans regia L.) genotypes selected from Tavas (Denizli). YYÜ Journal of Agricultural Science, 21(1), 42-48.

Doğan, M., \& Akgül, A. (2005). Fatty acid composition of some walnut (Juglans regia L.) cultivars from East Anatolia. Grasas y Aceites, 56(4), 328-331. https://doi.org/10.3989/gya.2005.v56.i4.101

Eskimez, İ., Polat, M., Korkmaz, N., \& Mertoğlu, K. (2019). Investigation of some blackberry cultivars in terms of phenological, yield and fruit characteristics. International Journal of Agriculture Forestry and Life Sciences, 3(2), 233-238.

Fjellstrom, R. G., \& Parfitt, D. E. (1994). Walnut (Juglans spp.) genetic diversity determined by restriction fragment length polymorphisms. Genome, 37, 690-700. https://doi.org/10.1139/g94-097

Food and Agriculture Organization. (2019). FAOSTAT Statistics. Retrieved June 30, 2019, from http://www.fao.org/faostat/en/\#data/QC

Gao, P., Liu, R., Jin, Q., \& Wang, X. (2019). Comparative study of chemical compositions and antioxidant capacities of oils obtained from two species of walnut: Juglans regia and Juglans sigillata. Food Chemistry, 279, 279-287. https://doi.org/10.1016/j.foodchem.2018.12.016

Gharibzahedi, S. M. T., Mousavi, S. M., Hamedi, M., \& Khodaiyan, F. (2014). Determination and characterization of kernel biochemical composition and functional compounds of Persian walnut oil. Journal of Food Science and Technology, 51(1), 34-42. https://doi.org/10.1007/s13197-011-0481-2

Godeanu, I., Baciu, A., Botu, M., \& Achim, G. (1997). Valuable walnut hybrids and selections for intensive growth in Romania. Acta Horticulturae, 442, 95-100. https://doi.org/10.17660/ActaHortic.1997.442.12

Gunn, B. F., Aradhya, M., Salick, J. M., Miller, A. J., Yongping, Y., Lin, L., \& Xian, H. (2010). Genetic variation in walnuts (Juglans regia and J. sigillata; Juglandaceae): Species distinctions, human impacts, and the conservation of agrobiodiversity in Yunnan, China. American Journal of Botany, 97(4), 660-671. https://doi.org/10.3732/ajb.0900114

Jahanbani, R., Ghaffari, S. M., Salami, M., Vahdati, K., Sepehri, H., Sarvestani, N. N., Sheibani, N., \& Moosavi-Movahedi, A. A. (2016). Antioxidant and anticancer activities of walnut (Juglans regia L.) protein hydrolysates using different proteases. Plant Foods Human Nutrition, 71(4), 402-409. https://doi.org/10.1007/s11130-016-0576-Z

James, C. S. (1995). Analytical chemistry of foods. Springer. https://doi.org/10.1007/978-14615-2165-5

Kacar, B., \& İnal, A. (2008). Bitki analizleri [Plant analysis]. Nobel Yayın Dağıtım.

Kafkas, E., Burgut, A., Ozcan, H., Ozcan, A., Sutyemez, M., Kafkas, S., \& Türemis, N. (2017). Fatty acid, total phenol and tocopherol profiles of some walnut cultivars: A comparative study. Food and Nutrition Sciences, 8(12), 1074-1084. https://doi.org/10.4236/fns.2017.812079

Kapluhan, E. (2015). Ziraat coğrafyasi açisindan bir inceleme: Kaman ilçesinde (Kirşehir) ceviz üretim faaliyetleri [An investigation of agriculture for geography: Walnut production activities in Kaman District (Kırşehir)]. Marmara Coğrafya Dergisi, 32, 147-170. https://doi.org/10.14781/mcd.68149

Keles, H., Akça, Y., \& Ercisli, S. (2014). Selection of promising walnut genotypes (Juglans regia L.) from inner Anatolia. Acta Scientiarum Polonorum, Hortorum Cultus, 13(3), $167-175$. 
Koyuncu, M. A., \& Așkın, A. (1995). Bitlis ili Adilcevaz yöresinden seçilmiș 12 ümitvar ceviz tipinin bileşim maddelerinin belirlenmesi üzerine bir araştırma [A study on the determination of the ingredients of 12 promising walnut types selected from the Adilcevaz region of Bitlis Province]. In Proceedings of II Horticulture Congress of Turkey, Adana, Turkey (pp. 475-478). Bahçe Bitkileri Derneği.

Koyuncu, M. A., Koyuncu, F., Yıldırım-Akıncı, F., Dilmaçünal, T., \& Vural, E. (2005). Gelincik (Isparta) doğal ceviz genotiplerinin yan dal verimliliği ve meyve özelliklerinin belirlenmesi [Determination of lateral fruitfulness and fruit characteristics of natural walnut (Juglans regia L.) genotypes of Gelincik (Isparta)]. Bahçe Ceviz, 34(1), 73-82.

Manirakiza, P., Covaci, A., \& Schepens, P. (2001). Comparative study on total lipid determination using Soxhlet, Roese-Gottlieb, Bligh \& Dyer, and modified Bligh \& Dyer extraction methods. Journal of Food Composition and Analysis, 14(1), 93-100. https://doi.org/10.1006/jfca.2000.0972

Martínez, M. L., Labuckas, D. O., Lamarque, A. L., \& Maestri, D. M. (2010). Walnut (Juglans regia L.): Genetic resources, chemistry, by-products. Journal of the Science of Food and Agriculture, 90(12), 1959-1967. https://doi.org/10.1002/jsfa.4059

McGranahan, G., \& Leslie, C. (1990). Walnuts (Juglans). In J. N. Moore, J. R. Ballington, et al. (Eds.), Genetic resources of temperate fruit and nut crops (pp. 907-974). International Society for Horticultural Science. https://doi.org/10.17660/ActaHortic.1991.290.20

Molnar, T. J., Zaurov, D. E., Capik, J. M., Eisenman, S. W., Ford, T., Nikolyi, L. V., \& Funk, C. R. (2011). Persian walnuts (Juglans regia L.) in Central Asia. Annual Report of the Northern Nut Growers Association, 101, 56-69.

Muradoğlu, F., \& Balta, F. (2010). Ahlat (Bitlis) Yöresinden selekte edilen cevizlerin (Juglans regia L.) bazı fiziksel ve kimyasal özellikleri [Some physical and chemical characteristics of promising walnuts (Juglans regia L.) genotypes selected from Ahlat (Bitlis)]. YYÜ Journal of Agricultural Sciences, 20(1), 41-45.

NMKL NordVal International. (2007). Trace elements - $\mathrm{As}, \mathrm{Cd}, \mathrm{Hg}, \mathrm{Pb}$ and other elements. Determination by ICP-MS after pressure digestion (NMKL 186). NMKL NordVal International.

Nunes, P. X., Silva, S. F., Guedes, R. J., \& Almeida, S. (2012). Biological oxidations and antioxidant activity of natural products. In R. Venketeshwer (Ed.), Phytochemicals as nutraceuticals. Global approaches to their role in nutrition and health (pp. 1-20). https://doi.org/10.5772/26956

Oğuz, H. İ., Erdoğan, O., \& Gökdoğan, O. (2017). Niğde yöresinde Chandler ve Franquette ceviz (Juglans regia L.) çeşitlerinin verim ve kalite performanslarının belirlenmesi [Determination of the yield and quality performances in the Niğde District of Chandler and Franquette walnut (Juglans regia L.) cultivars]. Bahçe, 46(Special issue 2), 233-240.

Okatan, V., Polat, M., Ercişli, S., \& Aşkın, M. A. (2017). Some pomological and chemical properties of local pear varieties in Uşak, Turkey. Scientific Papers, Series B, Horticulture, 61, 11-13.

Örmeci, D., \& Aşkın, M. A. (2017). Nursery performance of apple nursery plants in different ecological conditions. International Journal of Agriculture, Forestry and Life Sciences, $1(1), 52-60$.

Patumi, M., Andria, G. D., Fontanazza, G., Morelli, P., Giorgio, P., \& Sorrentino, G. (1999). Yield and oil quality of intensively trained trees of three cultivars of olive (Olea europea L.) under different irrigation regimes. The Journal of Horticultural Science and Biotechnology, 74(6), 729-737. https://doi.org/10.1080/14620316.1999.11511180

Poggetti, L., Ermacora, P., Cipriani, G., Pavan, F., \& Testolin, R. (2017). Morphological and carpological variability of walnut germplasm (Juglans regia L.) collected in NorthEastern Italy and selection of superior genotypes. Scientia Horticulturae, 225, 615-619. https://doi.org/10.1016/j.scienta.2017.07.056

Polat, M., Okatan, V., \& Güçlü, S. F. (2015). Determination of some physical and chemical properties of walnut (Juglans regia L.) genotypes grown in the central district of Bitlis/Turkey. Scientific Papers, Series B, Horticulture, 59, 81-86. https://doi.org/10.13140/RG.2.1.1901.1041

Savage, G. P. (2001). Chemical composition of walnuts (Juglans regia L.) grown in New Zealand. Plant Foods for Human Nutrition, 56, 75-82. https://doi.org/10.1023/A:1008175606698

Soylu, A., \& Ertürk, Ü. (2001). Bazı ceviz çeşitlerinde apomiktik tohum oluşumu üzerinde araştırmalar [Research on apomictic seed formation in some walnut varieties]. In Proceedings of First National Walnut Symposium, Tokat, Turkey (pp. 133-137). Gaziosmanpasa University. 
Şen, S. M. (1980). Kuzeydoğu anadolu ve doğu karadeniz bölgesi cevizlerinin (Juglans regia L.) seleksiyon yoluyla ıslahı üzerinde araştırmalar [Research on breeding of Northeast Anatolia and Eastern Black Sea region walnuts (Juglans regia L.) by selection] [Unpublished doctoral dissertation]. Atatürk University.

Şimşek, M. (2010). Selection of walnut types with high fruit bearing and quality in Şanlıurfa population. International Journal of the Physical Sciences, 5(7), 992-996.

Şimşek, M. (2016). Chemical, mineral and fatty acid compositions of various types of walnut (Juglans regia L.) in Turkey. Bulgarian Chemical Communications, 48(1), 66-70.

Tapia, M. I., Sanchez-Margado, J. R., Garcia-Parra, J., Ramirez, R., Hernandez, T., \& GonzalesGames, D. (2013). Comparative study of the nutritional and bioactive compounds content of four walnut (Juglans regia L.) cultivars. Journal of Food Composition and Analysis, 31, 232-237. https://doi.org/10.1016/j.jfca.2013.06.004

United States Department Agriculture. (2016). USDA National Nutrient Database for Standard Reference, release 28. https://data.nal.usda.gov/system/files/sr28_doc.pdf

United States Department of Agriculture. (2016). 2015 California walnut acreage report. https://walnuts.org/report/acreage-report-2015/

Usanmaz, S., Öztürkler, F., Helvacı, M., Alas, T., Kahramanoğlu, İ., \& Aşkın, M. A. (2018). Effects of periods and altitudes on the phenolic compounds and oil contents of olives, cv. Ayvalık. International Journal of Agriculture, Forestry and Life Science, 2(2), 32-39.

Ünver, H., \& Çelik, M. (2005). Ankara yöresi cevizlerinin (Juglans regia L.) seleksiyon yoluyla 1slahı [Studies on varietal selection in walnut (Juglans regia L.) populations of Ankara Province]. Bahçe Ceviz, 34(1), 83-89.

Valdebenito, D., Faris, D., Oyanedel, E., Castro, M., Lampinen, B., Tixier, A., \& Saa, S. (2017). The morphology of a walnut (Juglans regia L.) shoot is affected by its position in the canopy and correlated to the number and size of its fruits. Scientia Horticulturae, 220, 303-309. https://doi.org/10.1016/j.scienta.2017.03.046

Wan, C., Chen, C., Li, M., Yang, Y., Chen, M., \& Chen, J. (2017). Chemical constituents and antifungal activity of Ficus hirta Vahl. fruits. Plants, 6(4), Article 44. https://doi.org/10.3390/plants6040044

Woodroof, J. G. (1967). Tree nuts: Production, processing, products. AVI Pub.

Yang, L. X. (2005). Effect of water extracts of larch on growth of Manchurian walnut seedings. Journal of Forestry Research, 16(4), 285-288. https://doi.org/10.1007/BF02858190

Yarilgaç, T., Koyuncu, F., Koyuncu, M. A., Kazankaya, A., \& Şen, S. M. (2001). Some promising walnut selections (Juglans regia L.). Acta Horticulturae, 544, 93-96. https://doi.org/10.17660/ActaHortic.2001.544.10

Yarılgaç, T., Özrenk, T., Muradoğlu, F., \& Tüfenkçi, Ş. (2003). Gevaş yöresinden selekte edilmiş bazı cevizlerin (Juglans regia L.) pomolojik özellikleri ve makro-mikro element düzeyleri [Some macro-micro nutrient concentrations and pomological traits of selected walnuts (Juglans regia L.) from Gevaş District]. YYÜ Journal of Agricultural Sciences, 13(1), 33-37.

Yarılgaç, T., \& Yılmaz, K. (2016). Çal (Denizli) yöresinden selekte edilmiş bazı ceviz genotiplerinin fiziksel ve biyokimyasal özellikleri [Physical and biochemical characteristics of some walnut genotypes selected from Çal (Denizli) region]. Anadolu Journal of Agricultural Sciences, 31, 9-15. https://doi.org/10.7161/anajas.2016.31.1.9-15

Yerlikaya, C., Yucel, S., Erturk, Ü., \& Korukluoğlu, M. (2012). Proximate composition, minerals and fatty acid composition of Juglans regia L. genotypes and cultivars grown in Turkey. Brazilian Archives of Biology and Technology, 55(5), 677-683. https://doi.org/10.1590/S1516-89132012000500006

Yılmazer, M., \& Seçilmiş, H. (2006). Bazı serbest yağ asitlerinin metanolik HCL ortamında türevlendirilmesindeki koşulların incelenmesi [Investigation of conditions for derivatization of some free fatty acids in methanolic HCL medium]. In III Ulusal Analitik Kimya Kongresi Bildiri özetleri [III National Analytical Chemistry Congress abstracts] (p. 25). Çanakkale Onsekiz Mart Üniversitesi Yayınları. 